\title{
Recent advances in the molecular biology of the protist parasite Trichomonas vaginalis
}

\author{
David Leitsch ${ }^{*}$
}

${ }^{1}$ Department of Specific Prophylaxis and Tropical Medicine, Medical University of Vienna, Vienna, Austria

\begin{abstract}
Trichomonas vaginalis is an anaerobic/microaerophilic protist parasite which causes trichomoniasis, one of the most prevalent sexually transmitted diseases worldwide. T. vaginalis not only is important as a human pathogen but also is of great biological interest because of its peculiar cell biology and metabolism, in earlier times fostering the erroneous notion that this microorganism is at the root of eukaryotic evolution. This review summarizes the major advances in the last five years in the T. vaginalis field with regard to genetics, molecular biology, ecology, and pathogenicity of the parasite.
\end{abstract}

\section{Keywords}

Trichomonas vaginalis, Sexually Transmitted Diseases, Microbiome

\section{Peer Review}

The peer reviewers who approve this article are:

1. Augusto Simoes-Barbosa, School of Biological Sciences, Faculty of Science, University of Auckland, Auckland, New Zealand

Competing interests: No competing interests were disclosed.

2. Natalia de Miguel, Laboratorio de Parásitos Anaerobios, Instituto Tecnológico Chascomús, National Scientific and Technical Research Council, National University of San Martin (CONICET-UNSAM), Chascomús, Argentina

Competing interests: No competing interests were disclosed.

3. Paola Rappelli, Department of Biomedical Sciences, University of Sassari, Sassari, Italy Competing interests: No competing interests were disclosed. 
*Corresponding author: David Leitsch (david.leitsch@meduniwien.ac.at)

Competing interests: The author declares that he has no competing interests.

Grant information: The author declares that no grants were involved in supporting this work.

Copyright: (c) 2021 Leitsch D. This is an open access article distributed under the terms of the Creative Commons Attribution License, which permits unrestricted use, distribution, and reproduction in any medium, provided the original work is properly cited.

How to cite this article: Leitsch D. Recent advances in the molecular biology of the protist parasite Trichomonas vaginalis. Faculty Reviews 2021 10:(26) https://doi.org/10.12703/r/10-26

Published: 04 Mar 2021, Faculty Reviews 10:(26) https://doi.org/10.12703/r/10-26 


\section{Introduction}

The protist parasite Trichomonas vaginalis is the causative agent of trichomoniasis, one of the most prevalent sexually transmitted diseases worldwide. In the most recent estimate by the World Health Organization ${ }^{1}$, 110 million infections worldwide were ascribed to $T$. vaginalis in 2016; that is somewhat less than ascribed to chlamydia but much more than to gonorrhea and syphilis. Symptoms of trichomoniasis are usually more severe in women than in men and affect the vagina, the cervix, or the urethra or a combination of these. Vaginal pruritus and odorous vaginal discharge are the most common sequelae, but severe inflammation of the cervix can also occur. In men, T. vaginalis can cause urethritis and prostatitis, albeit with lower frequency. Trichomoniasis can persist for years and sour the life of those infected, but it also increases the risk for adverse pregnancy outcomes and the risk of acquiring $\mathrm{HIV}^{2}$. It is now firmly established that underlying trichomoniasis increases the risk to acquire HIV by 1.5 - to 2 -fold ${ }^{3}$. This poses serious problems in countries where both pathogens are highly endemic (for example, in the southern part of Africa). $T$. vaginalis has also been suggested to predispose for cervical cancer and prostate cancer, although there is far less support for this supposed $\operatorname{link}^{4-6}$ than with HIV.

However, T. vaginalis not only is of medical importance but also is a fascinating microorganism in its own right. Once considered a primordial eukaryote because of its anaerobic metabolism and the absence of mitochondria, it is now known to host hydrogenosomes ${ }^{7}$, hydrogen gas-producing organelles derived from mitochondria. Furthermore, T. vaginalis, like other trichomonads, has a huge haploid genome of $160 \mathrm{Mb}$ which contains a very large number of transposable elements (TEs) ${ }^{8}$. T. vaginalis is commonly believed to be asexual and to exist only as a trophozoite-stage flagellate, but the recent discovery of meiosis-specific genes ${ }^{9}$, amongst other features typical of sexual organisms, and of a cyst-like stage with a cell wall ${ }^{10}$ might lead to a revaluation of these tenets.

The present overview focuses on the major scientific advances in the $T$. vaginalis field in the last five years and covers genetics, biochemistry, cell biology, ecology, and infection biology of the parasite. Drug testing and resistance will also be discussed. However, more clinical aspects of trichomoniasis, such as epidemiology, diagnosis, and management, were surveyed recently in another review published at F1000 Research ${ }^{11}$ and are not included here.

\section{Genome and gene expression}

As compared with other protists, $T$. vaginalis has an enormously large genome of $160 \mathrm{Mb}$ in length ${ }^{12}$, which encodes about 60,000 protein-coding genes. A surprisingly large portion of the genome consists of TEs ${ }^{13,14}$, and as many as 40,000 TEs come from several families. This has slowed down efforts to assemble the genome because of the immensely high number of sequence repeats. Still, the availability of the genome sequence, if not fully assembled, has allowed substantial scientific advances on $T$. vaginalis evolution on the one hand and on its genetic machinery on the other.
Strikingly, $T$. vaginalis has a predicted number of only 62 introns. A detailed study on introns in $T$. vaginalis confirmed the existence of 32 genes with introns, whereas 18 candidates were found to be non-functional as they were not removed from the respective transcripts ${ }^{15}$. Eleven new introns which group into two different types with regard to sequence and splice motifs were identified in this study. Transcription of protein-encoding genes is commonly initiated at an initiator element ${ }^{16}$ or two alternative promoter elements, M3 and M5, respectively ${ }^{17}$. Interestingly, the M3 element resembles a Myb recoginition element and was found to be bound by a novel transcription factor with a Myb-like DNA-binding domain ${ }^{17}$. Surprisingly, however, a TATA box was found to be missing from promoters of protein-encoding genes. T. vaginalis nonetheless does encode two TATA box-binding proteins (TBPs) which bind to initiator-binding protein 39 (IBP39) ${ }^{16}$ and to DNA as determined in electrophoretic mobility shift assays ${ }^{18}$. However, it seems that binding to DNA by these T. vaginalis TBPs is unspecific $^{19}$. Instead, they might have a role in the transcription of spliceosomal U6 snRNA. Also of interest is the mRNA capping apparatus in $T$. vaginalis which is structurally similar to its counterparts in metazoans and plants rather than to those in other protists ${ }^{20}$.

Transcription rates not only are determined by sequences proximal to the transcription start site but also are dependent on epigenetic regulation. Consequently, epigenetic regulation in $T$. vaginalis was addressed in a number of studies. N6-methyladenine (6mA) was found to be the major DNA methylation mark in $T$. vaginali ${ }^{21}$. It occurs frequently in intergenic regions (in $94 \%$ of all sequenced methylated DNA stretches) and probably localizes to chromatin loops, indicating a role of $6 \mathrm{~mA}$ in the regulation of gene expression. Also, histone acetylation was identified as an important modulator of gene expression in two independent studies ${ }^{22,23}$. Indeed, T. vaginalis has a large arsenal of histone deacetylases (HDACs) of the Sir2 type and of histone acetyl transferases ${ }^{22}$. Methylation and acetylation of histone 3 (H3K27Ac and H3K4Me3, respectively) near transcription initiation sites were found to be positively correlated with transcription rate, and the HDAC inhibitor trichostatin A was found to strongly affect gene expression $^{23}$. Independently of the transcription rate, mRNA levels can also be regulated, a process termed RNA interference (RNAi). For RNAi, the presence of small RNAs (sRNAs), which are complementary to their target mRNA and recruit the so-called RNA-induced silencing complex, is a prerequisite. Importantly, two Argonaute proteins (T. vaginalis AGO1 and 2), which constitute central components of this complex, have been found in the genome ${ }^{14}$. Furthermore, a large number of sRNAs of the PIWI domain-interacting type (piRNA) were found. Arguably, T. vaginalis AGO1 and 2 interact with sequencespecific piRNA to degrade transposase mRNAs as encoded by myriads of TEs in the T. vaginalis genome ${ }^{14}$.

The last step of expression of protein-coding genes (that is, translation) has also been studied in recent years. Translation efficiency of transcripts was found to be tuned by stretches of low sequence complexity at the $5^{\prime}$ end of the mRNA, 
followed by a highly structured region more downstream ${ }^{24}$. The newly introduced iLOV fluorescent protein $^{25}$ was used as a marker to gauge the effect of the prospective regulatory sequences on protein expression.

In addition to the fundamental research on $T$. vaginalis genetics as stated above, the repertoire of genetic tools in this parasite was refined and enlarged. In a comprehensive study, reference genes for quantitative polymerase chain reaction studies were evaluated ${ }^{26}$. Importantly, the frequently chosen glyceraldehyde 3-phosphate dehydrogenase $(G A P D H)$ gene was identified as highly unreliable when exposing $T$. vaginalis to various conditions due to the strongly variable expression levels observed. In contrast, the genes for DNA topisomerase 2, $\alpha$-tubulin, and actin were found to be much more suitable; the best dual combination was DNA topisomerase 2 and $\alpha$-tubulin. Hopefully, these results will be taken into account in future studies on gene expression in $T$. vaginalis. Furthermore, RNAi was applied successfully for the first time in $T$. vaginalis $^{27}$, although downregulation of the respective transcripts was rather low (33-72\% at the most), which might be insufficient for many scientific questions. As a word of caution, the feasibility of the method still awaits confirmation from other researchers in the field. In the meantime, gene knockouts using CRISPR/ Cas-9 technology might prove highly instrumental. In a pilot study $^{28}$, CRISPR/Cas-9 was successfully applied to knock out the non-essential genes for ferredoxin-1 and migration inhibitory factor. Importantly, the efficiency of the necessary transfection procedures was highly improved when a newly developed nucleofection protocol was applied.

\section{Cell biology and biochemistry}

$T$. vaginalis diverges strongly from most other protists by having an anaerobic metabolism and by hosting an unusual organelle, the hydrogenosome. These issues have attracted considerable interest throughout the last 50 years, and the last five years have yielded further important insights into the physiology of this parasite.

The hydrogenosome was originally believed to have evolved from a bacterial endosymbiont in a trichomonad progenitor but is now known to derive from mitochondria ${ }^{29}$. Many biological processes relating to hydrogenosomal function, however, remained incompletely understood in the past. Protein import into hydrogenosomes, for example, is of pivotal importance as no protein translation takes place within the organelle. Some hydrogenosomal proteins have an N-terminal targeting sequence (NTS) but others do not ${ }^{30,31}$. Moreover, in many cases, the NTS seems to be dispensable for protein import, and even ectopic import into yeast mitochondria without NTS is possible ${ }^{31,32}$. This indicates that predominantly internal signals earmark certain proteins for import into hydrogenosomes. In the case of tail-anchored (TA) proteins which localize to the $T$. vaginalis hydrogenosome $\mathrm{e}^{33}$, the responsible amino acid sequences have been studied in more detail: in the $\mathrm{C}$-terminal region next to the trans-membrane domain of TA proteins, the net charge must be positive to ensure reliable import. The translocase of the outer membrane (TOM) complex is mainly responsible for conducting protein import into the hydrogenosome ${ }^{34}$. The translocation channel is mainly formed by TvTOM40-2 which is divergent from TOM40 proteins from other eukaryotes but which nevertheless can partially complement for TOM40 mutations in yeast $^{34}$. Despite its apparent simplicity, the protein import machinery of the hydrogenosome is highly effective. In recent decades, there was an intense discussion about whether certain highly expressed hydrogenosomal proteins such as pyruvate:ferredoxin oxidoreductase (PFOR), malic enzyme, and succinyl-coA synthetase (SCS) are also trafficked to the cell surface to act there as adhesin proteins, facilitating adhesion to host epithelium. This issue has now been conclusively settled by a recent study which showed that these enzymes are exclusively trafficked into the hydrogenosomes ${ }^{35}$. However, trafficking of proteins to membrane compartments in general (that is, to destinations including the hydrogenosome but not being restricted to it) seems to have a different underlying mechanism as demonstrated for the cyclophilins TvCyP1 and TvCyP2 $2^{36}$.

The major hydrogenosomal pathway deploys PFOR, SCS, malic enzyme, and hydrogenase for the breakdown of pyruvate and malate to carbon dioxide and hydrogen gas. But also pathways for amino acid catabolism are hosted in the organelle. These become more important under glucose restriction, especially the arginine dihydrolase pathway ${ }^{37}$. The arginine dehydrolase pathway also indirectly leads to the formation of nitric oxide (NO) levels and this has a stabilizing effect on hydrogenosomal membranes under glucose restriction ${ }^{38}$. Several hydrogenosomal enzymes (for example, PFOR and hydrogenase) are sensitive to oxygen and its derivatives such as hydrogen peroxide and superoxide radical anion and need to be protected by appropriate antioxidant enzymes (reviewed in 39). The most recently discovered antioxidant enzyme of the hydrogenosome is the osmotically inducible protein $\mathrm{C}$ (OsmC), which detoxifies peroxides after receiving electrons from lipoate via the glycine decarboxylase $\mathrm{L}$ and $\mathrm{H}$ proteins ${ }^{40}$.

Pyruvate and malate are broken down in the hydrogenosome but derive from glycolysis taking place in the cytosol. Glucose, in turn, is obtained mostly from the breakdown of intracellular glycogen ${ }^{41}$ or of glycogen from the vaginal environment. $T$. vaginalis secretes several glycosidases ${ }^{42}$ (including most notably $\beta$-amylase ${ }^{43,44}$ ), which break down glycogen to maltose. Maltose is further broken down to glucose by another glucosidase ${ }^{45}$, followed by glucose import into the cell. Of course, carbohydrate uptake is not the only form of nutrient uptake $T$. vaginalis is capable of. The hydrolysis of nucleotides from the host by $T$. vaginalis ectonucleoside triphosphate diphosphohydrolase (E-NTPDase) and the subsequent uptake of the resulting nucleosides have been studied in a suite of studies in recent years ${ }^{46,47}$.

\section{Trichomonas vaginalis as a member of the vaginal microbiome}

The main habitat of $T$. vaginalis, the human vagina, accommodates a highly complex microbiome ${ }^{48}$ which strongly influences 
the chances of $T$. vaginalis to successfully colonize its host. The microbiota of the vagina are roughly grouped into five community state types (CSTs) of which four (CST-I, -II, -III, and $-\mathrm{V}$ ) are dominated by lactobacilli, whereas CST-IV is dominated by anaerobic bacteria such as Gardnerella vaginalis and mollicutes such as Mycoplasma spp. ${ }^{49}$. Lactobacilli preserve an acidic environment ( $\mathrm{pH} \sim 4.5$ ), whereas CST-IV leads to a higher vaginal $\mathrm{pH}$. T. vaginalis is predominantly associated with CST-IV $^{50}$. The presence of certain anaerobic bacteria (that is, Prevotella amnii and Sneathia sanguinegens) is positively correlated with the acquisition of $T$. vaginali ${ }^{51}$. Interestingly, representatives of the CST-IV microbiome enhance adherence of T. vaginalis to epithelial cells through formation of a biofilm ${ }^{52}$ and both can cooperatively compromise the integrity of the vaginal epithelium by disrupting intercellular tight junctions ${ }^{53}$. In contrast, lactobacilli clearly antagonize $T$. vaginalis. In a revelatory study, Lactobacillus gasseri strain ATCC $9857^{54}$ was shown to strongly inhibit adhesion of $T$. vaginalis to host cells in a contact-dependent manner. In fact, L. gasseri ATCC 9857 could even displace already-adhering trichomonads from vaginal epithelial cells. Arguably, aggregation-promoting factor 2 (APF-2) as encoded by the lactobacilli is responsible for this remarkable capability. T. vaginalis, however, is by no means defenseless. It expresses nine peptidoglycan hydrolases of the NlpC/P60 family which can kill bacteria ${ }^{55}$. To date, these enzymes have been tested only on Escherichia coli and it will be interesting to learn more about their activity against vaginal bacteria.

Even if most details of the interplay of $T$. vaginalis with the microbiota of the vagina remain to be discovered, the association of $T$. vaginalis with mollicutes, predominantly with Mycoplasma spp., has been studied in considerable detail. The proportion of $T$. vaginalis isolates harboring Mycoplasma hominis varies strongly depending on geographic origin but usually is substantial and can be even higher than $80 \%{ }^{56}$. Thus, coinfections with $T$. vaginalis and $M$. hominis are very common and therefore should be taken into account by all means when speaking of trichomoniasis. The interactions of $T$. vaginalis and $M$. hominis are mutually beneficial. Most importantly, the growth rate of $T$. vaginalis is greatly enhanced (that is, by 20\%) if intracellular M. hominis is present ${ }^{57}$. This is probably due to the arginine dihydrolase (ADH) pathway which is shared by the two microorganisms and which leads to the production of more ATP when L-arginine is present as a substrate. Indeed, intracellular $M$. hominis was shown to enhance ATP production substantially after supplementation with L-arginine whereas in symbiont-free $T$. vaginalis supplementation of arginine had only a minimal effect. This also has implications for the host defense because NO production by immune cells is greatly diminished if L-arginine is scavenged by the $T$. vaginalis/M. hominis consortium. There are probably many more interactions, and there is some evidence that $M$. hominis can alter gene expression in $T$. vaginalis to a certain extent ${ }^{58}$. Like T. vaginalis, $M$. hominis has been linked to adverse pregnancy outcomes ${ }^{59}$. There is an indication that the cohabitation with $T$. vaginalis promotes this, especially when $T$. vaginalis is eliminated by metronidazole treatment and liberated M. hominis infects host tissue ${ }^{60,61}$. In addition to M. hominis, another Mycoplasma species is closely associated with T. vaginalis: Mycoplasma girerdii. This species was discovered only recently ${ }^{62}$, possibly because it might exist merely as an intracellular symbiont of $T$. vaginalis. A recent study, however, casts doubt on this notion ${ }^{51}$. In any case, $M$. girerdii is at least as common as $M$. hominis ${ }^{63}$ but its pathogenic potential remains to be elucidated.

In addition to hosting bacterial symbionts, $T$. vaginalis hosts T. vaginalis virus (TVV), which is grouped into four strains (TVV1-4) and belongs to the family of Totiviridae ${ }^{64}$. Little is known about the life cycle of TVV but it has been suggested to exacerbate trichomoniasis by enhancing the immune response ${ }^{65}$, and a recent study showed that the presence of TVV mitigates the response of vaginal epithelial cells to trichomonads ${ }^{66}$. However, another recent study of $355 \mathrm{~T}$. vaginalis isolates, of which $40 \%$ hosted TVV, did not find any association of TVV and clinical symptoms ${ }^{67}$.

\section{Pathogenesis of trichomoniasis}

After a long period of scientific neglect, the pathogenesis of trichomoniasis is now finally receiving the attention it deserves. In recent years, pertinent studies have been forthcoming in increasing numbers, covering numerous aspects ranging from host response to parasite virulence factors (reviewed in 68).

Arguably the most significant response of the host to $T$. vaginalis is the production of cytokines by immune cells at the site of infection. Mainly interleukin 1 (IL-1), IL-6, IL-8, and IL-17 $7^{69-71}$ are induced and this is characteristic of a pro-inflammatory response. Interestingly, the cytokine profile was influenced by the presence of the $M$. hominis as IL-1 and IL-6 levels were several-fold higher after exposure to $T$. vaginalis G3 with the endosymbiont as compared with the same strain without ${ }^{69}$. Notably, IL-6 was reported to induce polarization of THP-1-derived macrophages into M2-type macrophages ${ }^{72}$ and IL-1 production is linked to activation of the NLRP3 inflammasome in macrophages resulting in processing of precursor IL-1 $\beta$ to bioactive IL- $1^{73}$. IL- 1 , in turn, can induce pyroptotic cell death in macrophages ${ }^{73}$. The host cell response to T. vaginalis further centers on Toll-like receptor 2 (TLR2), whose expression is also triggered by $T$. vaginalis $^{71,74}$. Consequently, in $\mathrm{TLR}^{-/}$mouse macrophages, immune mediators such as p38, ERK, and p65 NF- $\mathrm{BB}$ were found to be phosphorylated to a lesser extent after stimulation with $T$. vaginalis $^{75}$. In contrast to these observations, intraepithelial dendritic cells and regulatory $\mathrm{T}$ cells were shown to react to exposure with T. vaginalis or one of its major antigens, actinin-2, with the expression of IL-10, which is an anti-inflammatory cytokine ${ }^{75}$. Cytokine production, however, is not restricted to the human host as $T$. vaginalis also produces cytokines to ensure its survival. The parasite secretes a homologue of human macrophage migration inhibition factor (TvMIF), which increases survivability under serum starvation several-fold ${ }^{76}$. Serum contains several essential nutrients for $T$. vaginalis, such as 
amino acids, lipids, and precursors of nucleotides. T. vaginalis also secretes leukotriene B4 (LTB4), which induces exocytotic degranulation in mast cells, thereby promoting tissue inflammation ${ }^{77}$.

T. vaginalis interacts with the host tissue by shedding extracellular vesicles (EVs) carrying cargo which promotes the infection process (thoroughly reviewed in 78). Two types of T. vaginalis EVs have been identified: exosomes $(50-150 \mathrm{~nm})^{79}$ and microvesicles ${ }^{80}$, which are considerably larger $(100-1000 \mathrm{~nm})$. The former derive from intracellular multivesicular bodies whereas the latter are shed from the cell membrane. The vesicles contain protein factors involved in mediating adherence, such as tetraspanins or BspA-domain proteins, and arguably in tuning the host's response. Notably, the content of the small vesicles was found to be altered in the presence of $\mathrm{TVV}^{66}$. In addition to proteins, EVs contain $\mathrm{RNA}^{81}$; that is, mainly tRNA fragments or tRNA halves (tsRNA), respectively, which have also been described to be part of the cargo in EVs of trypanosomatid parasites ${ }^{82,83}$. The precise role of tsRNA in host-parasite interactions, however, remains to be elucidated. Finally, the uptake of exosomes by host cells is mediated by 4- $\alpha$-glucanotransferase (Tv4AGT) on the EV surface which binds to heparan sulfate of host cell surface proteoglycans ${ }^{84}$.

Adherence of $T$. vaginalis to host epithelium is indeed a key event in trichomoniasis. In this process, the host's surface proteins galectin- $1^{85}$ and $-3^{86}$ have an essential role by binding to lipoglycan (LG) on the parasite's surface ${ }^{85}$. Host galectins are also instrumental in dimming the host response to $T$. vaginalis, and TvLG binding can further tune this ${ }^{86}$. However, numerous other cell surface-associated factors, such as a novel cadherin-like $\operatorname{protein}^{87}$, actinin- $2^{88}$, and triosephosphate isomerase ${ }^{89}$, promote adherence of $T$. vaginalis to host epithelium. The last of these is a glycolytic protein which can also be associated with the parasite's cell surface and bind to fibronectin and laminin. Two other groups of proteins, the BspA and Pmp domain-containing proteins, seem to enhance adherence ${ }^{90}$, and the former have been found to be transported to the host in $\mathrm{EVs}^{79}$. Finally, palmitoylation of proteins was found to positively affect adherence of $T$. vaginalis to host cells ${ }^{91}$.

Eventually, adherence is followed by cell lysis. Damage to host cells can be inflicted by parasite proteases such as metalloprotease TvMP50 $0^{92}$ or cysteine proteinase $2(\mathrm{CP} 2)^{93,94}$, and antibody treatment against either of these factors greatly diminished cytotoxicity as exerted by $T$. vaginalis. Interestingly, $T$. vaginalis cysteine proteases do also degrade the anion channel CFTR on the host cell surface, leading to elevated intracellular $\mathrm{Cl}^{-}$concentrations and induction of NF- $\mathrm{KB}$ signaling ${ }^{95}$. Another protease, the rhomboid protease TvROM1, exerts an indirect effect by cleaving $T$. vaginalis substrate proteins, resulting in enhanced attachment and damage to host cells ${ }^{96}$. Just recently, saponin-like pore-forming proteins (TvSaplips) were identified in the $T$. vaginalis genome ${ }^{97}$ and one of these, TvSaplip12, was expressed and characterized. TvSaplip12 is strongly upregulated upon contact with host cells and has a strong lytic activity against bacteria and HeLa cells. Consequently, it has been proposed to act as a Trichopore, in accordance with Amoebapore in Entamoeba histolytica ${ }^{98}$. To summarize, the picture of pathogenesis of trichomoniasis is still incomplete but the gaps are being filled at an increasing pace.

\section{Anti-trichomonadal drugs: established and experimental}

Throughout the last six decades, the 5-nitroimidazole drug metronidazole has remained the mainstay of anti-trichomonadal chemotherapy $^{99}$, although resistance has become an increasingly worrying issue. Clinical metronidazole resistance is a complex phenomenon affecting numerous enzymatic pathways in $T$. vaginalis $^{99}$. In a large-scale study on gene expression in metronidazole-sensitive and -resistant strains ${ }^{13}$, several genes were found to be differentially expressed in three metronidazole-resistant strains assayed. Flavin reductase 1 (FR1), an oxygen-scavenging enzyme which produces hydrogen peroxide, had been previously identified as a mediator of metronidazole resistance ${ }^{100}$ and was found to be downregulated in all three isolates. Various nitroreductases, likewise identified previously ${ }^{101-103}$, were also downregulated. In contrast, multidrug resistance pump and metal $A B C$ transporter genes were upregulated in all three resistant strains. The relative contribution of all of these factors to metronidazole resistance remains to be determined.

Importantly, treatment failures with metronidazole are not always caused by resistance as such. Treatment regimens can also strongly affect treatment outcome. It was demonstrated recently that a seven-day course with $500 \mathrm{mg}$ metronidazole twice per day is clearly more effective than a single dose with $2 \mathrm{~g}^{104}$. In addition, it is necessary to test alternative treatments within the drug class of 5-nitroimidazoles, such as secnidazole ${ }^{105}$ or novel derivatives ${ }^{106,107}$.

Cross resistance, however, is often a problem with 5-nitroimidazole drugs, so completely different drugs have also been explored for anti-trichomonadal activity. Arguably, the most promising candidate is auranofin, a repurposed anti-rheumatic drug which was shown to be effective against a larger number of parasites ${ }^{108}$. Indeed, auranofin is also effective against $T$. vaginalis and can cure experimentally infected mice ${ }^{109}$. It was also successfully administered topically in mice on nanoparticles suspended in a hydrogel ${ }^{110}$. Thioredoxin reductase has been proposed to be the main target of auranofin, but this needs further confirmation as observations in another parasitic anaerobic flagellate, Giardia lamblia, contradict this notion ${ }^{111}$. Numerous other candidate drugs, including proteasome inhibitors such as carmaphycin-17 $7^{112}$, zinc sulfate and zinc complexes ${ }^{113,114}$, bisbenzimidazole analogues $^{115}$, boric acid $^{116}$, and tetracycline ${ }^{117}$, were also evaluated. For a more complete overview of recent anti-trichomonadal drug research, a comprehensive review is available ${ }^{118}$.

As a concluding note, it is important to emphasize that assay conditions can be of very high importance when evaluating efficacies of established and novel anti-trichomonadal drugs. 
For example, cysteine, which is routinely used in growth media for $T$. vaginalis, has a highly protective effect against metronidazole and auranofin ${ }^{119}$.

\section{Concluding remarks}

During the writing of this review, it became quickly apparent that the number of high-quality research articles in the T. vaginalis field has increased in the last five years as compared with the preceding quinquennial period ${ }^{120}$, a development which is also reflected in a larger number of references cited in this review. This is highly encouraging and indicates that $T$. vaginalis now receives more attention than before. There were substantial advances in our understanding of how $T$. vaginalis interacts with its host and, equally important, with the microbiome of which it is a part. As to the latter, the formation of consortia of protistologists, bacteriologists, and mycologists might even accelerate the pace of insightful discoveries in the future.
1. Rowley J, Vander Hoorn S, Korenromp E, et al.: Chlamydia, gonorrhoea, trichomoniasis and syphilis: Global prevalence and incidence estimates, 2016. Bull World Health Organ. 2019; 97(8): 548-562P.

PubMed Abstract | Publisher Full Text | Free Full Text | Faculty Opinions Recommendation

2. Kissinger P: Trichomonas vaginalis: A review of epidemiologic, clinical and treatment issues. BMC Infect Dis. 2015; 15: 307 PubMed Abstract | Publisher Full Text | Free Full Text | Faculty Opinions Recommendation

3. Masha SC, Cools P, Sanders EJ, et al.: Trichomonas vaginalis and HIV infection acquisition: A systematic review and meta-analysis. Sex Transm Infect. 2019; 95(1): 36-42.

PubMed Abstract | Publisher Full Text | Free Full Text |

Faculty Opinions Recommendation

4. Ghosh I, Muwonge R, Mittal S, et al:: Association between high risk human papillomavirus infection and co-infection with Candida spp. and Trichomonas vaginalis in women with cervical premalignant and malignant lesions. J Clin Virol. 2017: 87: 43-8. PubMed Abstract | Publisher Full Text

5. Shui IM, Kolb S, Hanson C, et al:: Trichomonas vaginalis infection and risk of advanced prostate cancer. Prostate. 2016; 76(7): 620-3. PubMed Abstract | Publisher Full Text | Free Full Text

6. Tsang SH, Peisch SF, Rowan B, et al:: Association between Trichomonas vaginalis and prostate cancer mortality. Int J Cancer. 2019; 144(10): 2377-80. PubMed Abstract | Publisher Full Text | Free Full Text

7. Lindmark DG, Müller M: Hydrogenosome, a Cytoplasmic Organelle of the Anaerobic Flagellate Tritrichomonas foetus, and Its Role in Pyruvate Metabolism. J Biol Chem. 1973; 248(22): 7724-8. PubMed Abstract | Publisher Full Text

8. Conrad MD, Bradic M, Warring SD, et al:: Getting trichy: Tools and approaches to interrogating Trichomonas vaginalis in a post-genome world. Trends Parasitol. 2013; 29(1): 17-25

PubMed Abstract | Publisher Full Text | Free Full Text

9. Bradic M, Carlton JM: Does the common sexually transmitted parasite Trichomonas vaginalis have sex? PLOS Pathog. 2018; 14(3): e1006831. PubMed Abstract | Publisher Full Text | Free Full Text | Faculty Opinions Recommendation

10. Beri D, Yadav P, Devi HRN, et al:: Demonstration and Characterization of Cyst-Like Structures in the Life Cycle of Trichomonas vaginalis. Front Cell Infect Microbiol. 2019; 9: 430.

PubMed Abstract | Publisher Full Text | Free Full Text |

Faculty Opinions Recommendation

11. van Gerwen OT, Muzny CA: Recent advances in the epidemiology, diagnosis, and management of Trichomonas vaginalis infection [version 1; peer review: 2 approved]. F1000Res. 2019; 8. PubMed Abstract | Publisher Full Text | Free Full Text

12. Carlton JM, Hirt RP, Silva JC: Draft genome sequence of the sexually transmitted pathogen Trichomonas vaginalis. Science. 2007; 315(5809): 207-12. PubMed Abstract | Publisher Full Text | Free Full Text | Faculty Opinions Recommendation

13. C Bradic M, Warring SD, Tooley GE, et al.: Genetic Indicators of Drug Resistance in the Highly Repetitive Genome of Trichomonas vaginalis. Genome
Biol Evol. 2017: 9(6): 1658-72.

PubMed Abstract | Publisher Full Text | Free Full Text |

Faculty Opinions Recommendation

14. Warring SD, Blow F, Avecilla G, et al:: Small RNAs Are Implicated in Regulation of Gene and Transposable Element Expression in the Protist Trichomonas vaginalis. $m$ Sphere. 2021; 6(1): e01061-20. PubMed Abstract | Publisher Full Text | Free Full Text | Faculty Opinions Recommendation

15. Wang SE, Amir AS, Nguyen T, et al.: Spliceosomal introns in Trichomonas vaginalis revisited. Parasit Vectors. 2018; 11(1): 607. PubMed Abstract | Publisher Full Text | Free Full Text Faculty Opinions Recommendation

16. Liston DR, Lau AO, Ortiz D, et al:: Initiator recognition in a primitive eukaryote: IBP39, an initiator-binding protein from Trichomonas vaginalis. Mol Cell Biol. 2001; 21(22): 7872-82.

PubMed Abstract | Publisher Full Text | Free Full Text | Faculty Opinions Recommendation

17. Smith AJ, Chudnovsky L, Simoes-Barbosa A, et al.: Novel core promoter elements and a cognate transcription factor in the divergent unicellular eukaryote Trichomonas vaginalis. Mol Cell Biol. 2011; 31(7): 1444-58. PubMed Abstract | Publisher Full Text | Free Full Text

18. Parra-Marín O, Rosas-Hernández L, López-Pacheco K, et al.: An in vitro characterisation of the Trichomonas vaginalis TATA box-binding proteins (TBPs). Parasitol Res. 2019; 118(10): 3019-31.

PubMed Abstract | Publisher Full Text

19. Simoes-Barbosa A, Hirt RP, Johnson PJ: A metazoan/plant-like capping enzyme and cap modified nucleotides in the unicellular eukaryote Trichomonas vaginalis. PLoS Pathog. 2010; 6(7): e1000999.

PubMed Abstract | Publisher Full Text | Free Full Text

20. Simoes-Barbosa A, Meloni D, Wohlschlegel JA, et al:: Spliceosomal snRNAs in the unicellular eukaryote Trichomonas vaginalis are structurally conserved but lack a 5'-cap structure. RNA. 2008; 14(8): 1617-31. PubMed Abstract | Publisher Full Text | Free Full Text

21. Lizarraga A, O'Brown ZK, Boulias K, et al.: Adenine DNA methylation, 3D genome organization, and gene expression in the parasite Trichomonas vaginalis. Proc Natl Acad Sci U S A. 2020; 117(23): 13033-43. PubMed Abstract | Publisher Full Text | Free Full Text | Faculty Opinions Recommendation

22. S Song MJ, Kim M, Choi Y, et al:: Epigenome mapping highlights chromatinmediated gene regulation in the protozoan parasite Trichomonas vaginalis. $\mathrm{Sci}$ Rep. 2017; 7: 45365.

PubMed Abstract | Publisher Full Text | Free Full Text Faculty Opinions Recommendation

23. N Pachano T, Nievas YR, Lizarraga A, et al: Epigenetics regulates transcription and pathogenesis in the parasite Trichomonas vaginalis. Cell Microbiol. 2017: 19(6): e12716.

PubMed Abstract | Publisher Full Text | Faculty Opinions Recommendation

24. W Wang SE, Brooks AES, Poole AM, et al: Determinants of translation efficiency in the evolutionarily-divergent protist Trichomonas vaginalis. $B M C$ Mol Cell Biol. 2020; 21(1): 54.

PubMed Abstract | Publisher Full Text | Free Full Text |

Faculty Opinions Recommendation 
25. Wang SE, Brooks AES, Cann B, et al:: The fluorescent protein iLOV outperforms eGFP as a reporter gene in the microaerophilic protozoan Trichomonas vaginalis. Mol Biochem Parasitol. 2017; 216: 1-4. PubMed Abstract | Publisher Full Text

26. dos Santos O, de Vargas Rigo G, Frasson AP, et al:: Optimal Reference Genes for Gene Expression Normalization in Trichomonas vaginalis. PLoS One. 2015 10(9): e0138331.

PubMed Abstract | Publisher Full Text | Free Full Text

27. Ravaee R, Ebadi P, Hatam G, et al:: Synthetic siRNAs effectively target cystein protease 12 and $\alpha$-actinin transcripts in Trichomonas vaginalis. Exp Parasitol. 2015; 157: 30-4.

PubMed Abstract | Publisher Full Text

28. Janssen BD, Chen YP, Molgora BM, et al:: CRISPR/Cas9-mediated gene modification and gene knock out in the human-infective parasite Trichomonas vaginalis. Sci Rep. 2018; 8(1): 270.

PubMed Abstract | Publisher Full Text | Free Full Text |

Faculty Opinions Recommendation

29. Hrdy I, Hirt RP, Dolezal P, et al.: Trichomonas hydrogenosomes contain the NADH dehydrogenase module of mitochondrial complex I. Nature. 2004; 432(7017): 618-22.

PubMed Abstract | Publisher Full Text | Faculty Opinions Recommendation

30. Mentel M, Zimorski V, Haferkamp P, et al:: Protein import into hydrogenosomes of Trichomonas vaginalis involves both $\mathrm{N}$-terminal and internal targeting signals: A case study of thioredoxin reductases. Eukaryotic Cell. 2008; 7(10) $1750-7$

PubMed Abstract | Publisher Full Text | Free Full Text

31. Rada P, Makki AR, Zimorski V, et al.: N-Terminal Presequence-Independent Import of Phosphofructokinase into Hydrogenosomes of Trichomonas vaginalis. Eukaryotic Cell. 2015; 14(12): 1264-75.

PubMed Abstract | Publisher Full Text | Free Full Text

32. Garg S, Stölting J, Zimorski V, et al.: Conservation of Transit Peptide-Independen Protein Import into the Mitochondrial and Hydrogenosomal Matrix. Genome Biol Evol. 2015; 7(9): 2716-26.

PubMed Abstract | Publisher Full Text | Free Full Text

33. Rada $\mathrm{P}$, Makki A, Žárský $\mathrm{V}$, et al:: Targeting of tail-anchored proteins to Trichomonas vaginalis hydrogenosomes. Mol Microbiol. 2019; 111(3): 588-603. PubMed Abstract | Publisher Full Text

34. Makki A, Rada P, Žárský V, et al.: Triplet-pore structure of a highly divergent TOM complex of hydrogenosomes in Trichomonas vaginalis. PLOS Biol. 2019; 17(1): e3000098.

PubMed Abstract | Publisher Full Text | Free Full Text

35. Rada P, Kellerová P, Verner Z, et al:: Investigation of the Secretory Pathway in Trichomonas vaginalis Argues against a Moonlighting Function of Hydrogenosomal Enzymes. J Eukaryot Microbiol. 2019; 66(6): 899-910. PubMed Abstract | Publisher Full Text | Faculty Opinions Recommendation

36. CHsu HM, Huang YH, Aryal S, et al.: Endomembrane Protein Trafficking Regulated by a TvCyP2 Cyclophilin in the Protozoan Parasite, Trichomonas vaginalis. Sci Rep. 2020; 10(1): 1275.

PubMed Abstract | Publisher Full Text | Free Full Text |

Faculty Opinions Recommendation

37. Huang KY, Ong SC, Wu CC, et al:: Metabolic reprogramming of hydrogenosomal amino acids in Trichomonas vaginalis under glucose restriction. J Microbiol Immunol Infect. 2019; 52(4): 630-7.

PubMed Abstract | Publisher Full Text

38. Cheng WH, Huang KY, Huang PJ, et al:: Nitric oxide maintains cell survival of Trichomonas vaginalis upon iron depletion. Parasit Vectors. 2015; 8: 393 PubMed Abstract | Publisher Full Text | Free Full Text

39. Leitsch D, Williams CF, Hrdý I: Redox Pathways as Drug Targets in Microaerophilic Parasites. Trends Parasitol. 2018; 34(7): 576-89. PubMed Abstract | Publisher Full Text

40. Nývltová E, Smutná T, Tachezy J, et al:: OsmC and incomplete glycine decarboxylase complex mediate reductive detoxification of peroxides in hydrogenosomes of Trichomonas vaginalis. Mol Biochem Parasitol. 2016; 206(1-2): 29-38.

PubMed Abstract | Publisher Full Text

41. Wilson WA, Pradhan P, Madhan N, et al:: Glycogen synthase from the parabasalian parasite Trichomonas vaginalis: An unusual member of the starch/glycogen synthase family. Biochimie. 2017; 138: 90-101. PubMed Abstract | Publisher Full Text

42. Huffman RD, Nawrocki LD, Wilson WA, et al:: Digestion of glycogen by a glucosidase released by Trichomonas vaginalis. Exp Parasitol. 2015; 159: 151-9. PubMed Abstract | Publisher Full Text

43. Smith RW, Brittingham A, Wilson WA: Purification and identification of amylases released by the human pathogen Trichomonas vaginalis that are active towards glycogen. Mol Biochem Parasitol. 2016; 210(1-2): 22-31. PubMed Abstract | Publisher Full Text

44. Štáfková J, Rada P, Meloni D, et al:: Dynamic secretome of Trichomonas vaginalis: Case study of $\beta$-amylases. Mol Cell Proteomics. 2018; 17(2): 304-20. PubMed Abstract | Publisher Full Text | Free Full Text
45. ter Kuile BH, Müller M: Maltose utilization by extracellular hydrolysis followed by glucose transport in Trichomonas vaginalis. Parasitology. 1995; 110(Pt 1): 37-44.

PubMed Abstract | Publisher Full Text

46. Frasson AP, dos Santos O, Meirelles LC, et al:: Five putative nucleoside triphosphate diphosphohydrolase genes are expressed in Trichomonas vaginalis. FEMS Microbiol Lett. 2016; 363(2): fnv221.

PubMed Abstract | Publisher Full Text

47. Menezes CB, Durgante J, de Oliveira RR, et al.: Trichomonas vaginalis NTPDase and ecto-5'-nucleotidase hydrolyze guanine nucleotides and increase extracellular guanosine levels under serum restriction. Mol Biochem Parasitol. 2016; 207(1): 10-8.

PubMed Abstract | Publisher Full Text

48. Pekmezovic M, Mogavero S, Naglik JR, et al:: Host-Pathogen Interactions during Female Genital Tract Infections. Trends Microbiol. 2019; 27(12): 982-96. PubMed Abstract | Publisher Full Text

49. Ravel J, Gajer P, Abdo Z, et al:: Vaginal microbiome of reproductive-age women. Proc Natl Acad Sci U S A. 2011; 108 Suppl 1(Suppl 1): 4680-7. PubMed Abstract | Publisher Full Text | Free Full Text | Faculty Opinions Recommendation

50. Brotman RM, Bradford LL, Conrad M, et al:: Association between Trichomonas vaginalis and vaginal bacterial community composition among reproductiveage women. Sex Transm Dis. 2012; 39(10): 807-12. PubMed Abstract | Publisher Full Text | Free Full Text

51. Jarrett OD, Srinivasan S, Richardson BA, et al.: Specific Vaginal Bacteria Are Associated With an Increased Risk of Trichomonas vaginalis Acquisition in Women. J Infect Dis. 2019; 220(9): 1503-10. PubMed Abstract | Publisher Full Text | Free Full Text Faculty Opinions Recommendation

52. Hinderfeld AS, Simoes-Barbosa A: Vaginal dysbiotic bacteria act as pathobionts of the protozoal pathogen Trichomonas vaginalis. Microb Pathog. 2020; 138: 103820 .

PubMed Abstract | Publisher Full Text | Faculty Opinions Recommendation

53. Hinderfeld AS, Phukan N, Bär AK, et al:: Cooperative Interactions between Trichomonas vaginalis and Associated Bacteria Enhance Paracellular Permeability of the Cervicovaginal Epithelium by Dysregulating Tight Junctions. Infect Immun. 2019; 87(5): e00141-19.

PubMed Abstract | Publisher Full Text | Free Full Text |

Faculty Opinions Recommendation

54. Phukan N, Brooks AES, Simoes-Barbosa A: A Cell Surface AggregationPromoting Factor from Lactobacillus gasseri Contributes to Inhibition of Trichomonas vaginalis Adhesion to Human Vaginal Ectocervical Cells. Infect Immun. 2018; 86(8): e00907-17.

PubMed Abstract | Publisher Full Text | Free Full Text |

Faculty Opinions Recommendation

55. Pinheiro J, Biboy J, Vollmer W, et al.: The Protozoan Trichomonas vaginalis Targets Bacteria with Laterally Acquired NIpC/P60 Peptidoglycan Hydrolases. MBio. 2018; 9(6): e01784-18.

PubMed Abstract | Publisher Full Text | Free Full Text

56. Fichorova R, Fraga J, Rappelli $\mathrm{P}$, et al:: Trichomonas vaginalis infection in symbiosis with Trichomonasvirus and Mycoplasma. Res Microbiol. 2017; 168(9-10): 882-91.

PubMed Abstract | Publisher Full Text

57. Margarita V, Rappelli $P$, Dessì D, et al:: Symbiotic Association with Mycoplasma hominis Can Influence Growth Rate, ATP Production, Cytolysis and Inflammatory Response of Trichomonas vaginalis. Front Microbiol. 2016; 7 and 953.

PubMed Abstract | Publisher Full Text | Free Full Text |

Faculty Opinions Recommendation

58. Fürnkranz U, Henrich B, Walochnik J: Mycoplasma hominis impacts gene expression in Trichomonas vaginalis. Parasitol Res. 2018; 117(3): 841-7. PubMed Abstract | Publisher Full Text | Free Full Text

59. Larsen B, Hwang J: Mycoplasma, Ureaplasma, and adverse pregnancy outcomes: A fresh look. Infect Dis Obstet Gynecol. 2010; 2010: 521921. PubMed Abstract | Publisher Full Text | Free Full Text

60. Margarita V, Fiori PL, Rappelli P: Impact of Symbiosis Between Trichomonas vaginalis and Mycoplasma hominis on Vaginal Dysbiosis: A Mini Review. Front Cell Infect Microbiol. 2020; 10: 179.

PubMed Abstract | Publisher Full Text | Free Full Text

61. Thi Trung Thu T, Margarita V, Cocco AR, et al.: Trichomonas vaginalis Transports Virulent Mycoplasma hominis and Transmits the Infection to Human Cells after Metronidazole Treatment: A Potential Role in Bacterial Invasion of Fetal Membranes and Amniotic Fluid. J Pregnancy. 2018; 2018: 5037181. PubMed Abstract | Publisher Full Text | Free Full Text

62. Fettweis JM, Serrano MG, Huang B, et al:: An emerging mycoplasma associated with trichomoniasis, vaginal infection and disease. PLOS ONE. 2014; 9(10): e110943.

PubMed Abstract | Publisher Full Text | Free Full Text 
63. Ioannidis A, Papaioannou P, Magiorkinis E, et al.: Detecting the Diversity of Mycoplasma and Ureaplasma Endosymbionts Hosted by Trichomonas vaginalis Isolates. Front Microbiol. 2017; 8: 1188 PubMed Abstract | Publisher Full Text | Free Full Text

64. Graves KJ, Ghosh AP, Kissinger PJ, et al.: Trichomonas vaginalis virus: A review of the literature. Int J STD AIDS. 2019; 30: 496-504.

PubMed Abstract | Publisher Full Text

65. Fichorova RN, Buck OR, Yamamoto HS, et al:: The villain team-up or how Trichomonas vaginalis and bacterial vaginosis alter innate immunity in concert. Sex Transm Infect. 2013; 89(6): 460-6. PubMed Abstract | Publisher Full Text | Free Full Text

66. Govender Y, Chan T, Yamamoto HS, et al.: The Role of Small Extracellular Vesicles in Viral-Protozoan Symbiosis: Lessons From Trichomonasvirus in an Isogenic Host Parasite Model. Front Cell Infect Microbiol. 2020; 10: 591172. PubMed Abstract | Publisher Full Text | Free Full Text | Faculty Opinions Recommendation

67. Graves KJ, Ghosh AP, Schmidt N, et al.: Trichomonas vaginalis Virus Among Women With Trichomoniasis and Associations With Demographics, Clinical Outcomes, and Metronidazole Resistance. Clin Infect Dis. 2019; 69(12): 2170-6. PubMed Abstract | Publisher Full Text | Free Full Text | Faculty Opinions Recommendation

68. Mercer F, Johnson PJ: Trichomonas vaginalis: Pathogenesis, Symbiont Interactions, and Host Cell Immune Responses. Trends Parasitol. 2018; 34(8): 683-93

PubMed Abstract | Publisher Full Text

69. Mercer F, Diala FGI, Chen YP, et al.: Leukocyte Lysis and Cytokine Induction by the Human Sexually Transmitted Parasite Trichomonas vaginalis. PLoS Negl Trop Dis. 2016; 10(8): e0004913.

PubMed Abstract | Publisher Full Text | Free Full Text

70. Olmos-Ortiz LM, Barajas-Mendiola MA, Barrios-Rodiles M, et al.: Trichomonas vaginalis exosome-like vesicles modify the cytokine profile and reduce inflammation in parasite-infected mice. Parasite Immunol. 2017; 39(6): e12426. PubMed Abstract | Publisher Full Text

71. Han IH, Kim JH, Kim SS, et al:: Signalling pathways associated with IL-6 production and epithelial-mesenchymal transition induction in prostate epithelial cells stimulated with Trichomonas vaginalis. Parasite Immunol. 2016; 38(11): 678-87.

PubMed Abstract | Publisher Full Text

72. $\mathrm{Han}$ IH, Song HO, Ryu JS: IL-6 produced by prostate epithelial cells stimulated with Trichomonas vaginalis promotes proliferation of prostate cancer cells by inducing M2 polarization of THP-1-derived macrophages. PLOS Negl Trop Dis. 2020; 14(3): e0008126. PubMed Abstract | Publisher Full Text | Free Full Text | Faculty Opinions Recommendation

73. Riestra AM, Valderrama JA, Patras KA, et al.: Trichomonas vaginalis Induces NLRP3 Inflammasome Activation and Pyroptotic Cell Death in Human Macrophages. J Innate Immun. 2019; 11(1): 86-98. PubMed Abstract | Publisher Full Text | Free Full Text

74. Li L, Li X, Gong P, et al:: Trichomonas vaginalis Induces Production of Proinflammatory Cytokines in Mouse Macrophages Through Activation of MAPK and NF-KB Pathways Partially Mediated by TLR2. Front Microbiol. 2018; 9. 712 .

PubMed Abstract | Publisher Full Text | Free Full Text

75. Lee HY, Kim J, Ryu JS, et al:: Trichomonas vaginalis $\alpha$-Actinin 2 Modulates Host Immune Responses by Inducing Tolerogenic Dendritic Cells via IL-10 Production from Regulatory T Cells. Korean J Parasitol. 2017; 55: 375-84. PubMed Abstract | Publisher Full Text | Free Full Text

76. Chen YP, Twu O, Johnson PJ: Trichomonas vaginalis Macrophage Migration Inhibitory Factor Mediates Parasite Survival during Nutrient Stress. MBio. 2018; 9(3): e00910-18

PubMed Abstract | Publisher Full Text | Free Full Text

77. Min A, Lee YA, Kim KA, et al:: SNAP23-Dependent Surface Translocation of Leukotriene B (LTB, Receptor 1 Is Essential for NOX2-Mediated Exocytotic Degranulation in Human Mast Cells Induced by Trichomonas vaginalisSecreted LTB. Infect Immun. 2017; 85(1): e00526-16. PubMed Abstract | Publisher Full Text | Free Full Text

78. Nievas YR, Lizarraga A, Salas N, et al:: Extracellular vesicles released by anaerobic protozoan parasites: Current situation. Cell Microbiol. 2020; 22(11): e13257.

PubMed Abstract | Publisher Full Text

79. Twu O, de Miguel N, Lustig G, et al.: Trichomonas vaginalis exosomes deliver cargo to host cells and mediate host:parasite interactions. PLOS Pathog. 2013; 9: e1003482.

PubMed Abstract | Publisher Full Text | Free Full Text |

Faculty Opinions Recommendation

80. Nievas YR, Coceres VM, Midlej V, et al:: Membrane-shed vesicles from the parasite Trichomonas vaginalis: Characterization and their association with cell interaction. Cell Mol Life Sci. 2018; 75(12): 2211-26. PubMed Abstract | Publisher Full Text

81. Artuyants A, Campos TL, Rai AK, et al.: Extracellular vesicles produced by the protozoan parasite Trichomonas vaginalis contain a preferential cargo of tRNA-derived small RNAs. Int J Parasitol. 2020; 50(14): 1145-55. PubMed Abstract | Publisher Full Text

82. Garcia-Silva MR, Sanguinetti J, Cabrera-Cabrera F, et al.: A particular set of small non-coding RNAs is bound to the distinctive Argonaute protein of Trypanosoma cruzi: Insights from RNA-interference deficient organisms. Gene. 2014; 538(2): 379-84.

PubMed Abstract | Publisher Full Text

83. Lambertz U, Oviedo Ovando ME, Vasconcelos EJR, et al:: Small RNAs derived from tRNAs and rRNAs are highly enriched in exosomes from both old and new world Leishmania providing evidence for conserved exosomal RNA Packaging. BMC Genomics. 2015; 16(1): 151 PubMed Abstract | Publisher Full Text | Free Full Text

84. Rai AK, Johnson PJ: Trichomonas vaginalis extracellular vesicles are internalized by host cells using proteoglycans and caveolin-dependent endocytosis. Proc Natl Acad Sci U S A. 2019; 116(43): 21354-60. PubMed Abstract | Publisher Full Text | Free Full Text

85. Okumura CYM, Baum LG, Johnson PJ: Galectin-1 on cervical epithelial cells is a receptor for the sexually transmitted human parasite Trichomonas vaginalis. Cell Microbiol. 2008; 10(10): 2078-90. PubMed Abstract | Publisher Full Text | Free Full Text

86. Fichorova RN, Yamamoto HS, Fashemi T, et al:: Trichomonas vaginalis Lipophosphoglycan Exploits Binding to Galectin-1 and -3 to Modulate Epithelial Immunity. J Biol Chem. 2016; 291(2): 998-1013.

PubMed Abstract | Publisher Full Text | Free Full Text

87. Chen YP, Riestra AM, Rai AK, et al: A Novel Cadherin-like Protein Mediates Adherence to and Killing of Host Cells by the Parasite Trichomonas vaginalis. mBio. 2019; 10(3): e00720-19.

PubMed Abstract | Publisher Full Text | Free Full Text

88. Lee HY, Kim J, Park SJ: Role of $\alpha$-Actinin 2 in Cytoadherence and Cytotoxicity of Trichomonas vaginalis. J Microbiol Biotechnol. 2017; 27(10): 1844-54. PubMed Abstract | Publisher Full Text

89. Miranda-Ozuna JFT, Hernández-García MS, Brieba LG, et al.: The Glycolytic Enzyme Triosephosphate Isomerase of Trichomonas vaginalis Is a SurfaceAssociated Protein Induced by Glucose That Functions as a Laminin- and Fibronectin-Binding Protein. Infect Immun. 2016; 84(10): 2878-94. PubMed Abstract | Publisher Full Text | Free Full Text

90. Handrich MR, Garg SG, Sommerville EW, et al:: Characterization of the BspA and Pmp protein family of trichomonads. Parasit Vectors. 2019; 12(1): 406. PubMed Abstract | Publisher Full Text | Free Full Text

91. Nievas YR, Vashisht AA, Corvi MM, et al:: Protein Palmitoylation Plays an Important Role in Trichomonas vaginalis Adherence. Mol Cell Proteomics. 2018; 17(11): 2229-41.

PubMed Abstract | Publisher Full Text | Free Full Text |

Faculty Opinions Recommendation

92. Puente-Rivera J, Villalpando JL, Villalobos-Osnaya A, et al:: The 50kDa metalloproteinase TvMP50 is a zinc-mediated Trichomonas vaginalis virulence factor. Mol Biochem Parasitol. 2017; 217: 32-41.

PubMed Abstract | Publisher Full Text

93. Miranda-Ozuna JFT, Rivera-Rivas LA, Cárdenas-Guerra RE, et al:: Glucoserestriction increases Trichomonas vaginalis cellular damage towards HeLa cells and proteolytic activity of cysteine proteinases (CPs), such as TvCP2. Parasitology. 2019; 146(9): 1156-1166.

PubMed Abstract | Publisher Full Text

94. Rivera-Rivas LA, Lorenzo-Benito S, Sánchez-Rodríguez DB, et al:: The effect of iron on Trichomonas vaginalis TvCP2: A cysteine proteinase found in vaginal secretions of trichomoniasis patients. Parasitology. 2020; 147(7): 760-74. PubMed Abstract | Publisher Full Text

95. $\mathrm{Xu} \mathrm{JB}$, Zhang YL, Huang J, et al.: Increased intracellular $\mathrm{Cl}$ concentration mediates Trichomonas vaginalis-induced inflammation in the human vaginal epithelium. Int J Parasitol. 2019; 49(9): 697-704. PubMed Abstract | Publisher Full Text

96. Riestra AM, Gandhi S, Sweredoski MJ, et al.: A Trichomonas vaginalis Rhomboid Protease and Its Substrate Modulate Parasite Attachment and Cytolysis of Host Cells. PLoS Pathog. 2015; 11(12): e1005294. PubMed Abstract | Publisher Full Text | Free Full Text | Faculty Opinions Recommendation

97. Diaz N, Lico C, Capodicasa C, et al:: Production and Functional Characterization of a Recombinant Predicted Pore-Forming Protein (TVSAPLIP12) of Trichomonas vaginalis in Nicotiana benthamiana Plants. Fron Cell Infect Microbiol. 2020; 10: 581066.

PubMed Abstract | Publisher Full Text | Free Full Text |

Faculty Opinions Recommendation

98. Leippe M: Pore-forming toxins from pathogenic amoebae. Appl Microbiol Biotechnol. 2014; 98(10): 4347-53. PubMed Abstract | Publisher Full Text

99. Leitsch D: A review on metronidazole: An old warhorse in antimicrobial chemotherapy. Parasitology. 2019; 146(9): 1167-78. PubMed Abstract | Publisher Full Text

100. Leitsch $\mathrm{D}$, Janssen $\mathrm{BD}$, Kolarich $\mathrm{D}$, et al.: Trichomonas vaginalis flavin 
reductase 1 and its role in metronidazole resistance. Mol Microbiol. 2014; 91(1) 198-208.

PubMed Abstract | Publisher Full Text | Free Full Text

101. Pal D, Banerjee S, Cui J, et al.: Giardia, Entamoeba, and Trichomonas enzymes activate metronidazole (nitroreductases) and inactivate metronidazole (nitroimidazole reductases). Antimicrob Agents Chemother. 2009; 53(2): 458-64 PubMed Abstract | Publisher Full Text | Free Full Text

102. C Paulish-Miller TE, Augostini P, Schuyler JA, et al:: Trichomonas vaginalis metronidazole resistance is associated with single nucleotide polymorphisms in the nitroreductase genes $n$ tr $\mathbf{4}_{T V}$ and $n$ tr $6_{T V^{*}}$. Antimicrob Agents Chemother. 2014; 58(5): 2938-43.

PubMed Abstract | Publisher Full Text | Free Full Text |

Faculty Opinions Recommendation

103. Beltrán NC, Horváthová L, Jedelský PL, et al.: Iron-induced changes in the proteome of Trichomonas vaginalis hydrogenosomes. PLoS One. 2013; 8(5): e65148.

PubMed Abstract | Publisher Full Text | Free Full Text

104. Kissinger P, Muzny CA, Mena LA, et al.: Single-dose versus 7-day-dose metronidazole for the treatment of trichomoniasis in women: An open-label, randomised controlled trial. Lancet Infect Dis. 2018; 18(11): 1251-1259. PubMed Abstract | Publisher Full Text | Free Full Text

105. Ghosh AP, Aycock C, Schwebke JR: In Vitro Study of the Susceptibility of Clinical Isolates of Trichomonas vaginalis to Metronidazole and Secnidazole. Antimicrob Agents Chemother. 2018; 62: e02329-17. PubMed Abstract | Publisher Full Text | Free Full Text

106. Mandalapu D, Kushwaha B, Gupta S, et al.: 2-Methyl-4/5-nitroimidazole derivatives potentiated against sexually transmitted Trichomonas: Design, synthesis, biology and 3D-QSAR study. Eur J Med Chem. 2016; 124: 820-39. PubMed Abstract | Publisher Full Text

107. N Jarrad AM, Debnath A, Miyamoto Y, et al:: Nitroimidazole carboxamides as antiparasitic agents targeting Giardia lamblia, Entamoeba histolytica and Trichomonas vaginalis. Eur J Med Chem. 2016; 120: 353-62. PubMed Abstract | Publisher Full Text | Free Full Text | Faculty Opinions Recommendation

108. May HC, Yu JJ, Guentzel MN, et al.: Repurposing Auranofin, Ebselen, and PX-12 as Antimicrobial Agents Targeting the Thioredoxin System. Front Microbiol. 2018; 9: 336 PubMed Abstract | Publisher Full Text | Free Full Text | Faculty Opinions Recommendation

109. Hopper M, Yun JF, Zhou B, et al:: Auranofin inactivates Trichomonas vaginalis thioredoxin reductase and is effective against trichomonads in vitro and in vivo. Int $J$ Antimicrob Agents. 2016; 48(6): 690-4. PubMed Abstract | Publisher Full Text | Free Full Tex
110. Zhang $\mathrm{Y}$, Miyamoto $\mathrm{Y}$, Ihara $\mathrm{S}$, et al.: Composite thermoresponsive hydrogel with auranofin-loaded nanoparticles for topical treatment of vagina trichomonad infection. Adv Ther (Weinh). 2019; 2(12): 1900157. PubMed Abstract | Publisher Full Text | Free Full Text

111. Leitsch D, Müller J, Müller N: Evaluation of Giardia lamblia thioredoxin reductase as drug activating enzyme and as drug target. Int $J$ Parasitol Drugs Drug Resist. 2016; 6(3): 148-53.

PubMed Abstract | Publisher Full Text | Free Full Text

112. O'Donoghue AJ, Bibo-Verdugo B, Miyamoto $\mathrm{Y}$, et al.: $20 \mathrm{~S}$ Proteasome as a Drug Target in Trichomonas vaginalis. Antimicrob Agents Chemother. 2019; 63(11): e00448-19.

PubMed Abstract | Publisher Full Text | Free Full Text

113. Byun JM, Jeong DH, Kim YN, et al.: Experience of successful treatment of patients with metronidazole-resistant Trichomonas vaginalis with zinc sulfate: A case series. Taiwan J Obstet Gynecol. 2015; 54(5): 617-20. PubMed Abstract | Publisher Full Text

114. Gilboa-Garber N: Pseudomonas aeruginosa Lectins as a Model for Lectin Production, Properties, Applications and Functions. Zentralbl Bakteriol Mikrobiol Hyg A. 1988; 270(1-2): 3-15. PubMed Abstract | Publisher Full Text

115. Korosh $\mathrm{T}$, Bujans $\mathrm{E}$, Morada $\mathrm{M}$, et al.: Potential of bisbenzimidazole-analogs toward metronidazole-resistant Trichomonas vaginalis isolates. Chem Biol Drug Des. 2017; 90(4): 489-95. PubMed Abstract | Publisher Full Text

116. Backus KV, Muzny CA, Beauchamps LS: Trichomonas vaginalis Treated With Boric Acid in a Metronidazole Allergic Female. Sex Transm Dis. 2017; 44(2): 120.

PubMed Abstract | Publisher Full Text

117. Huang KY, Ku FM, Cheng WH, et al.: Novel insights into the molecular events linking to cell death induced by tetracycline in the amitochondriate protozoan Trichomonas vaginalis. Antimicrob Agents Chemother. 2015; 59(11): 6891-903. PubMed Abstract | Publisher Full Text | Free Full Text

118. Küng $E$, Fürnkranz $U$, Walochnik J: Chemotherapeutic options for the treatment of human trichomoniasis. Int J Antimicrob Agents. 2019; 53(2): 116-27. PubMed Abstract | Publisher Full Text

119. Leitsch D: Drug susceptibility testing in microaerophilic parasites: Cysteine strongly affects the effectivities of metronidazole and auranofin, a novel and promising antimicrobial. Int J Parasitol Drugs Drug Resist. 2017; 7(3): 321-327. PubMed Abstract | Publisher Full Text | Free Full Text

120. Leitsch D: Recent Advances in the Trichomonas vaginalis Field [version 1; peer review: 2 approved]. F1000Res. 2016; 5: F1000 Faculty Rev-162. PubMed Abstract | Publisher Full Text | Free Full Text 